\title{
Protective effect of grape seed and skin extract against high-fat diet-induced dyshomeostasis of energetic metabolism in rat lung
}

Mohamed El Ayed, Safwen Kadri', Maha Mabrouk, Ezzedine Aouani and Salem Elkahoui

\begin{abstract}
Background: Obesity is currently one of the major epidemics of this millennium and affects poeples throughout the world. It causes multiple systemic complications as it significantly interferes with respiratory function.

Objective: We aimed in the present work to study the effect of high fat diet (HFD) on lung oxidative stress and energy metabolism alterations, as well as the putative protection afforded by grape seed and skin extract (GSSE).

Methods: We started by characterizing the GSSE and its composition using gas chromatography coupled to mass spectrometry (GC-MS). We used a rat model of high-fat-diet and we evaluated the effect of GSSE on oxidative stress and energetic disturbances induced by HFD. We analyzed the effect of HFD on lung oxidative status by assessing lipid oxidation level, non-protein thiols (NPSH) and superoxide anion level... We also evaluated the effect of HFD on creatine kinase $(\mathrm{CK})$, malate dehydrogenase $(\mathrm{MDH})$ and mitochondrial complex IV.

Results: HFD induced body weight gain, increased lung weight and lipid content without affecting insulinemia and dropped adiponectemia. HFD also provoked on lung oxidative stress characterized by increased carbonylation ( $+95 \% ; p=0.0045)$, decreased of NPSH $(-32 \% ; p=0.0291)$ and inhibition of antioxidant enzyme activities such as glutathione peroxidase $(-25 \% ; p=0.0074)$. HFD also altered lung intracellular mediators as superoxide anion $\mathrm{O}^{2-}(+59 \% ; p=0.0027)$ and increased lung xanthine oxidase activity $(+27 \% ; p=0.0122)$. HFD induced copper depletion $(-24 \% ; p=0.0498)$ and lead $(-51 \%: p=0.0490)$ from the lung. Correlatively HFD decreased the copper associated enzyme tyrosinase $(-29 \% ; p=0.0500)$ and decreased glutamine synthetase activity ( $-31 \% ; p=0.0027)$. HFD altered also lung energy metabolism by increasing CK activity $(+22 \% ; p=0.0108)$ and decreasing MDH and mitochondrial complex IV activities (-28\%; $p=0.0120,-31 \% ; p=0.0086$ respectively). Importantly all these alterations were efficiently corrected with GSSE treatment.
\end{abstract}

Conclusion: In conclusion, GSSE has the potential to alleviate the deleterious lipotoxic effect of HFD on lung and it could find potential application in the protection against HFD-induced lung complications.

Keywords: Obesity, High-fat-diet, Lung, Grape seed and skin extract, Oxidative stress, Energy metabolism, Metal ions

\footnotetext{
* Correspondence: kadri_safwen@live.fr

Bioactive Substance Laboratory, Biotechnology Centre, Technopolis

Borj-Cedria, BP-901, 2050 Hammam-Lif, Tunis, Tunisia
}

(c) The Author(s). 2018 Open Access This article is distributed under the terms of the Creative Commons Attribution 4.0 International License (http://creativecommons.org/licenses/by/4.0/), which permits unrestricted use, distribution, and reproduction in any medium, provided you give appropriate credit to the original author(s) and the source, provide a link to the Creative Commons license, and indicate if changes were made. The Creative Commons Public Domain Dedication waiver (http://creativecommons.org/publicdomain/zero/1.0/) applies to the data made available in this article, unless otherwise stated. 


\section{Background}

In recent decades, the prevalence of obesity has increased dramatically, and it has become the most common metabolic disease worldwide, leading to a global epidemic [1]. Several systemic complications are associated with obesity, some of which lead to severe impairment of organs and tissues. These complications involve mechanical changes caused by the accumulation of adipose tissue and the numerous cytokines produced by adipocytes [2]. However, obesity- induced adipokine dysfunction promotes pulmonary diseases including asthma, chronic obstructive pulmonary disease and pulmonary hypertension. The effects of obesity on the respiratory system have been increasingly studied. The accumulation of fat in the body causes changes in respiratory physiology, with consequent impairment of various lung function parameters [3]. A high-fat diet is known to contribute to obesity. Little is known regarding the effect of a high-fat diet on pulmonary function, despite the dramatic increase in the prevalence of respiratory ailments [4].

Up to now, many bioactive food components like those found in grape have been shown to prevent from a wide array of chronic disorders linked to metabolic syndrome [5]. Grape seed and skin extract (GSSE) is a polyphenol rich mixture [6] commonly used as nutritional supplement [7]. GSSE exerts numerous biological activities and health-promoting properties such as antioxidant [8], lipid lowering [9], and anti-obesity effects [10]. The effect of grape polyphenols on experimentallyinduced obesity has been largely approached [11].

In the present work, we studied the potential antiobesity effect of high dosage GSSE in high-fat-diet (HFD)-induced obesity in rat, with an emphasis on the protection afforded against lipotoxicity-induced lung oxidative stress and energy metabolism alteration. Data mainly showed that obesity induced oxidative stress into lung and altered energy metabolism and that GSSE prevented efficiently from the disturbances elicited upon HFD treatment.

\section{Materials and methods}

\section{Grape seed and skin extract preparation}

Grape seed and skin extract was processed from a grape cultivar (Carignan) of Vitis vinifera from northern Tunisia. Seeds were manually separated from skin, airdried and grounded separately with a coffee grinder (FP 3121Moulinex) until a fine powder was obtained. Both powders were then mixed at 50:50 ratios on a dry weight basis in $10 \%$ ethanol $(v / v)$ at dark. After vigorous stirring and centrifugation at $10,000 \mathrm{~g}$ for $15 \mathrm{~min}$ at $4{ }^{\circ} \mathrm{C}$, supernatant containing soluble polyphenols was used. Total phenolic content was determined by the Folin-
Table 1 Phenolic levels in GSSE

\begin{tabular}{llll}
\hline Phenolics & $\mathrm{H} 2 \mathrm{O}$ & $10 \%$ ethanol & 100 ethanol \\
\hline $\begin{array}{l}\text { Total phenolics } \\
\text { (mg EGA/ g Extract) }\end{array}$ & $0.68 \pm 0.02$ & $0.71 \pm 0.01$ & $0.83 \pm 0.02$ \\
$\begin{array}{l}\text { Total flavonoids } \\
\text { (mg EC/g Extract) }\end{array}$ & $0.16 \pm 0.01$ & $0.19 \pm 0.01$ & $0.20 \pm 0.01$ \\
$\begin{array}{l}\text { Condensed Tannins } \\
\text { (mg EC/g Extract) }\end{array}$ & $0.02 \pm 0.01$ & $0.06 \pm 0.02$ & $0.14 \pm 0.04$ \\
\hline
\end{tabular}

Ciocalteau colorimetric method [12]. Additionally, the Dewanto et al. [13] and Sun et al. [14] methods have been used for flavonoid and condensed tannin determination respectively. GSSE composition was established using gas chromatography coupled with mass spectrometry (GC-MS) according to the procedures described by Erbing et al. [15].

Briefly, hydrolysis of GSSE was performed by treatment with $2 \mathrm{M}$ trifluoroacetic at $120{ }^{\circ} \mathrm{C}$ for $2 \mathrm{~h}$ and hydrolysates were converted into $100 \mu \mathrm{L}$ dichloromethane. Extracts were performed under diminished pressure under a stream of helium N60. For GC, a Agilent 7890A GC instrument. GC-MS (EI, $70 \mathrm{eV}$ ) was performed on a Agilent 5975C inert GC-MSD instrument with triple-axis detector. GSSE were analyzed on HP-5 capillary column (30 $\mathrm{m} \times 0.25 \mathrm{~mm}$ coated with $5 \%$ phenylmethylpolysiloxane $\times 0.25 \mu \mathrm{m}$ ) using the temperature program $150^{\circ} \mathrm{C}(1 \mathrm{~min}) ; 180{ }^{\circ} \mathrm{C}$ at $1{ }^{\circ} \mathrm{C} / \mathrm{min} ; 250{ }^{\circ} \mathrm{C}$ at $2{ }^{\circ} \mathrm{C} / \mathrm{min} ; 300{ }^{\circ} \mathrm{C}$ at $15{ }^{\circ} \mathrm{C} / \mathrm{min}$ and at $300{ }^{\circ} \mathrm{C}(10 \mathrm{~min})$.

Table 2 GC-MS data of phenolic compounds found in Carignan GSSE

\begin{tabular}{ll}
\hline Compounds & Relative abundance (\%) \\
\hline Tyrosol & 1.03 \\
Syringaldehyde & 0.23 \\
Vanillin & 0.14 \\
Protocatechin acid & 2.2 \\
7, 9-Di-tert-butyl-1-oxaspiro & 1.21 \\
(4, 5) deca-6, 9-diene-2, 8-Dione & \\
p- Coumaric acid & 0.54 \\
Ethyl ester gallic acid & 1.73 \\
Gallic acid & 12.84 \\
Ferulic acid & 0.27 \\
Squalen & 1.2 \\
Epicatechin & 35.21 \\
Catechin & 34.41 \\
Flavan-3-ol & 2.25 \\
Quercetin & 1.01 \\
Quercetin derivatives & 5.73 \\
\hline
\end{tabular}




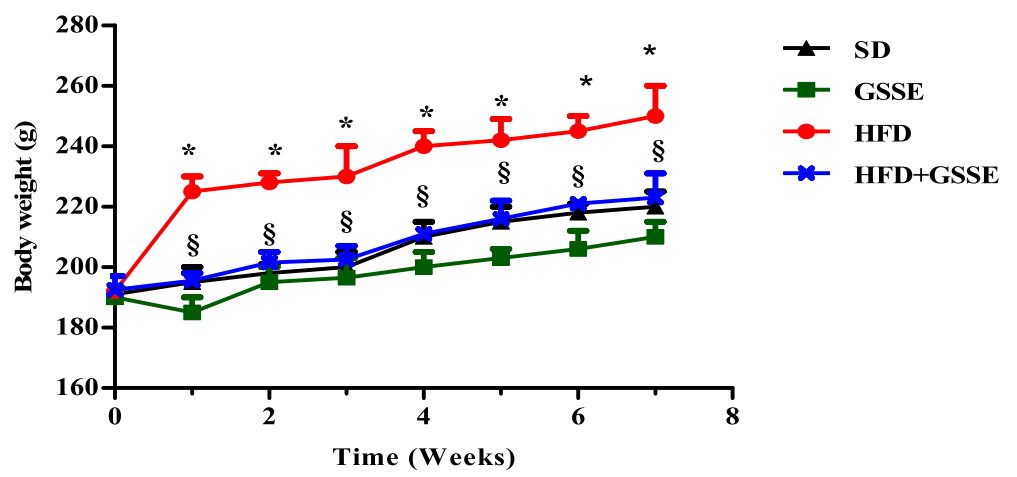

Fig. 1 Effect of HFD and GSSE on body weight evolution. Rats were fed a SD or HFD during 7 weeks and daily treated with GSSE $(4 \mathrm{~g} / \mathrm{kg})$. Results are expressed as mean \pm SEM $(N=6) . p<0.05$ was considered significant: $\left(^{*}\right)$ for HFD vs. SD, and $(\S)$ for HFD + GSSE vs. HFD. $\left(^{* *}\right)$ and $(\S \S)$ for $p<0.01$

\section{Animals diets and experimental design}

Twenty-four male Wistar rats (190-200 g) from Pasteur Institute Tunis were used in these experiments in accordance with the National Ethic Committee of Tunis University for use and care of animals in conformity with the NIH recommendations [16]. They were maintained in animal facility at a controlled temperature $\left(22 \pm 2{ }^{\circ} \mathrm{C}\right)$, a $12 \mathrm{~h}$ (light- dark) cycle, and divided into four groups of six animals each that were daily treated as follows:

Group1: SD: Rats fed Standard Diet (SD) and administered with $10 \%$ ethanol during 7 weeks.

Group 2: GSSE: Rats fed SD and treated with $4 \mathrm{~g} / \mathrm{kg}$ bw GSSE during 7 weeks.

Group 3: HFD: Rats fed High Fat Diet (HFD) and administered with $10 \%$ ethanol during7 weeks.

Group 4: HFD + GSSE: Rats fed HFD and treated with $4 \mathrm{~g} / \mathrm{kg}$ bw GSSE during 7 weeks.

SD for rodent in pellet was purchased from BADR Bizerte (Tunisia) and consisted of 3\% fat, 40\% carbohydrate, $14 \%$ protein. HFD was prepared by soaking commercial food pellets into warmed $\left(100{ }^{\circ} \mathrm{C}\right)$ and liquefied fat (peri-renal) of animal origin (sheep) for $15 \mathrm{~min}$ and allowed to dry at room temperature. HFD contained $28 \%$ fat, $32 \%$ carbohydrate, and $12 \%$ protein [17].

At the end of the treatment period, rats were anesthetized with urethane $\left(40 \mathrm{mg} . \mathrm{mL}^{-1}\right)$, sacrificed by decapitation. Blood was collected using heparin as anticoagulant.

\section{Tissue homogenization}

Lungs were isolated, weighed, and homogenized in phosphate buffered saline (PBS; $\mathrm{pH}=7.4 ; 50 \mathrm{mM}$ ) with an ultrathurax homogenizator. After centrifugation (10 min at $10000 \mathrm{~g}, 4{ }^{\circ} \mathrm{C}$ ), supernatant was frozen in liquid nitrogen and stored at $80{ }^{\circ} \mathrm{C}$ until assays. Body weight evolution was determined, lipids were extracted from whole lungs according to Folch et al. [18], and lung lipids conent was estimated.

\section{Plasma analyses}

Plasma insulin was measured using the ultrasensitive rat insulin ELISA Kit (Alpco Diagnostics) and adiponectin was measured using the Assay Max rat adiponectin ELISA Kit (Assay paro) [16].

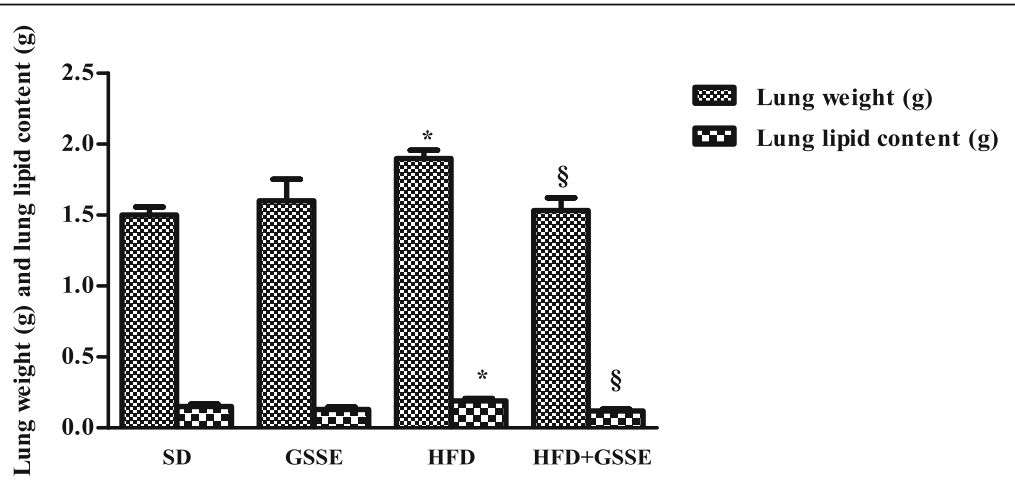

Fig. 2 Effect of HFD and GSSE on lung weight and lung lipids content. Results are expressed as mean \pm SEM $(N=6)$. $p<0.05$ was considered significant: (*) for HFD vs. SD, and (§) for HFD + GSSE vs. HFD. (**) and (§§) for $p<0.01$ 
Table 3 Effect of HFD and GSSE on plasma insulin and adiponectin

\begin{tabular}{lllll}
\hline & SD & GSSE & HFD & HFD + GSSE \\
\hline Plasmainsulin(ng/mL) & $1.50 \pm 0.00$ & $1.75 \pm 0.01$ & $1.25 \pm 0.01$ & $1.27 \pm 0.01$ \\
Plasmaadiponectin(ng/mL) & $6.20 \pm 0.02$ & $6.30 \pm 0.01$ & $2.75 \pm 0.04^{* *}$ & $4.95 \pm 0.02 \S$ \\
\hline
\end{tabular}

Results are expressed as mean \pm SEM $(N=6) . p<0.05$ was considered significant: $\left(^{*}\right)$ for HFD vs. SD, and $(\S)$ for HFD + GSSE vs. HFD. $\left({ }^{* *}\right)$ and $(\S \S)$ for $p<0.01$

\section{Biochemical analyses Lung carbonylation}

Oxidative damage to proteins was evaluated by quantifying protein carbonylation in lung homogenates according to Levine et al. [19]. Briefly, after proteins precipitation with $20 \%$ TCA and centrifugation at $11000 \mathrm{~g}$ for $3 \mathrm{~min}$ at $4{ }^{\circ} \mathrm{C}$, pellet was dissolved in $10 \mathrm{mM}$ dinitrophenylhydrazine (DNPH) containing phosphate buffer. After 3 washings with ethanolethylacetate (1:1), the last pellet obtained was dissolved in $20 \mathrm{mM}$ potassium phosphate $\mathrm{pH} 2.3$ containing $6 \mathrm{M}$ guanidine $\mathrm{HCl}$ and absorbance measured at $366 \mathrm{~nm}$ using the molar extinction coefficient of $22,000 \mathrm{M}^{-1}$. $\mathrm{cm}^{-1}$ and result expressed as mmol carbonyl protein/mg protein. Total soluble proteins were determined according to the biuret method [20]. Non-protein thiols (NPSH) were determined according to Ellman [21].

\section{Antioxidant glutathione peroxidase activity}

Lung homogenate were also used to evaluate endogenous antioxidant enzyme activity as glutathione peroxidase (GPx; EC 1.11.1.9) according to Charradi et al. [22]. Briefly, lung homogenate (2 $\mathrm{mg}$ protein) were mixed with phosphate buffer $100 \mathrm{mM} \mathrm{pH}=7.4$ containing $4 \mathrm{mmol} \mathrm{GSH}$ and $5 \mathrm{mmol} \mathrm{H} 2 \mathrm{O} 2$ in $1 \mathrm{~mL}$ final volume. The mixture was incubated at $37{ }^{\circ} \mathrm{C}$ for $1 \mathrm{~min}$; then, 0 . $5 \mathrm{~mL}$ TCA $(5 \%, w / v)$ was added to stop the reaction. After centrifugation at $1.500 \mathrm{~g}$ for $5 \mathrm{~min}, 0.2 \mathrm{~mL}$ supernatant was mixed with phosphate buffer $100 \mathrm{mmol} \mathrm{pH}$ = 7.4 containing $10 \mathrm{mmol} 2$-nitrobenzoc acid (DTNB). GPx activity was measured at $412 \mathrm{~nm}$.

\section{ROS measurement}

Lung superoxide radical was determined according to Marklund and Marklund. [23] with slight modifications. Briefly after incubation of brain homogenate in Tris$\mathrm{HCl}$ buffer $\mathrm{pH}=8.2$ at $25{ }^{\circ} \mathrm{C}$ for $10 \mathrm{~min}$, pyrogallol was added to the mixture and the incubation pursued at $25^{\circ} \mathrm{C}$ for four-minutes. The reaction was terminated by the addition of $\mathrm{HCl}$ and absorbance measured at $420 \mathrm{~nm}$ against the blank.

\section{Xanthine oxidase activity}

Lung xanthine oxidase (XO) activity (EC.1.17.3.2) was determined according to Avis et al. [24] The principle of this method is as follows: In the presence of xanthine, $\mathrm{XO}$ produced uric acid and absorbance measured at
$295 \mathrm{~nm}$ using the molar extinction coefficient of the acid uric $=9500 \mathrm{M}^{-1} \cdot \mathrm{cm}^{-1}$.

\section{Metals ions measurements and some enzymes activities}

Tissue samples were also washed in nitric acid (15. 5 mol. $\left.\mathrm{L}^{-1}\right)$, diluted, and filtered for copper and plumb measurements by atomic absorption spectroscopy. Tyrosinase activity (EC. 1.14.18.1) a copper $\left(\mathrm{Cu}^{2+}\right)$ dependent enzyme was determined using $\mathrm{L}$ - tyrosine as substrate in $50 \mathrm{mM}$ sodium phosphate buffer $\mathrm{pH}=6.5$ at $25{ }^{\circ} \mathrm{C}$ [25]. Glutamine synthetase (GS) activity (EC. 6.3.1.2) a Manganese $(\mathrm{Mn})$ containing enzyme was determined according to Santoro et al. [26]. Briefly, lung homogenate was added to assay mixture containing $50 \mathrm{mM}$ imidazole, $25 \mathrm{mM}$ arsenic, $0.16 \mathrm{mM}$ ADP, $50 \mathrm{mM}$ L-glutamine, $25 \mathrm{mM}$ hydroxylamine and $2 \mathrm{mM} \mathrm{MnCl} 2$. Incubation was carried out at $37{ }^{\circ} \mathrm{C}$ for one-hour and the reaction stopped by addition of two volumes of a ferric chloride solution containing $2.42 \%$ ferric chloride, $1.45 \%$ trichloroacetic acid (TCA) and $1.82 \% \mathrm{HCl}$. After centrifugation at $10000 \mathrm{~g}$ for $10 \mathrm{~min}$ absorbance of the supernatant was read at $540 \mathrm{~nm}$.

\section{Mitochondrial isolation}

Lung tissue was homogenized in mitochondrial isolation buffer containing $70 \mathrm{~mm}$ sucrose, $210 \mathrm{~mm}$ mannitol, $5 \mathrm{~mm}$ Tris $\mathrm{HCl}, 1 \mathrm{~mm}$ EDTA; $\mathrm{pH}=7.4$ and suspensions were centrifuged at $800 \mathrm{~g}, 4^{\circ} \mathrm{C}$, for $10 \mathrm{~min}$. The supernatant fluids were centrifuged at $13000 \mathrm{~g}, 4{ }^{\circ} \mathrm{C}$, for $10 \mathrm{~min}$, and the pellets were washed with mitochondrial isolation buffer and centrifuged at $13000 \mathrm{~g}, 4{ }^{\circ} \mathrm{C}$, for 10 min to obtain the crude mitochondrial fraction [27].

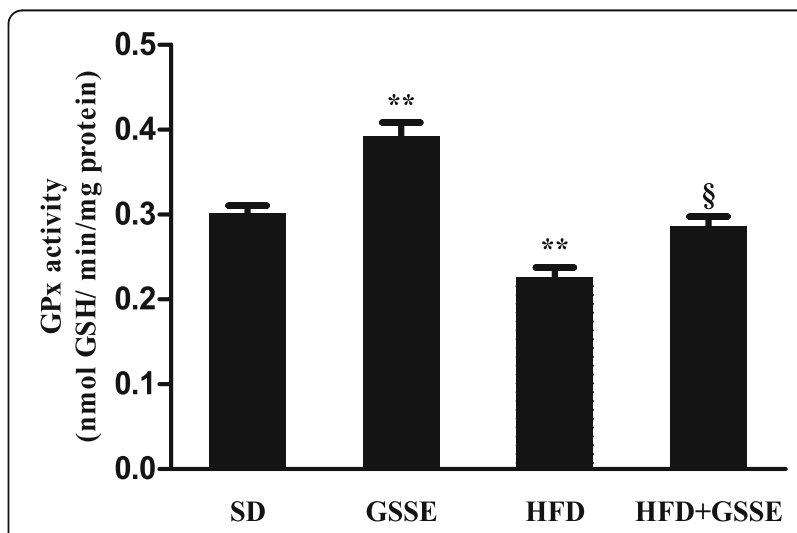

Fig. 3 Effect of HFD and GSSE on GPx activity. Results are expressed as mean \pm SEM $(N=6)$. $p<0.05$ was considered significant: $\left(^{*}\right)$ for HFD vs. SD, and (§) for HFD + GSSE vs. HFD. $\left({ }^{* *}\right)$ and $(\S \S)$ for $p<0.01$ 
Table 4 Effect of HFD and GSSE on lung protein carbonylation and NSPH

\begin{tabular}{lllll}
\hline & SD & GSSE & HFD & HFD + GSSE \\
\hline $\begin{array}{l}\text { Carbonyl protein } \\
\text { (mmol carbonylated protein/mg protein) }\end{array}$ & $0.0116 \pm 0.001249$ & $0.008 \pm 0.001528$ & $0.02267 \pm 0.001453^{* *}$ & $0.01667 \pm 0.0008819^{\S}$ \\
$\begin{array}{l}\text { NPSH } \\
\text { (mmol/mg protein) }\end{array}$ & $12.13 \pm 0.7535$ & $14.63 \pm 0.696$ & $8.233 \pm 0.8969^{*}$ & $11.73 \pm 0.5608^{\S}$ \\
\hline
\end{tabular}

Results are expressed as mean \pm SEM $(N=6) . p<0.05$ was considered significant: $\left(^{*}\right)$ for HFD vs. SD, and $(\S)$ for HFD + GSSE vs. HFD. $(* *)$ and $(\S \S)$ for $p<0.01$

\section{Mitochondrial enzymes activities}

Creatine kinase activity Creatine kinase (CK) activity (EC.2.7.3.2) was determined from mitochondrial fraction using a commercial kit from Biomaghreb, Tunisia. Briefly, CK was reactivated by $\mathrm{N}$-acetylcysteine and $\mathrm{CK}$ activity was measured following the decrease in $\mathrm{NADH}$ which absorbed at $340 \mathrm{~nm}$ and expressed as follows: $\Delta \mathrm{DO} / \mathrm{min} * 4130$.

Malate dehydrogenase activity The activity of malate dehydrogenase (MDH) (EC.1.1.1.37) was measured as described previously by Kitto [28] with slid modification. Aliquots $(20 \mu \mathrm{g}$ protein) were transferred into a medium containing $10 \mathrm{mM}$ rotenone, $0.2 \%$ Triton X-100, $0.15 \mathrm{mM}$ $\mathrm{NAD}$, and $100 \mathrm{mM}$ potassium phosphate buffer, $\mathrm{pH}$ 7.4, at $37^{\circ} \mathrm{C}$. The reaction was started by addition of $0.33 \mathrm{mM}$ malate. The absorbance was monitored at $340 \mathrm{~nm}$.

Activity of mitochondrial complex-IV Mitochondrial complex-IV (Cytochrome c oxidase, EC.1.9.3.1) activity was measured spectrophotometrically according to the method of Ragan et al. [29] as modified by Desai et al. (28) and it measured as the rate of oxidation of reduced cytochrome $\mathrm{c}$ by mitochondria at $30{ }^{\circ} \mathrm{C}$. The decrease in reduced cytochrome $\mathrm{c}$ was monitored at $550 \mathrm{~nm}$.

\section{Statistical analysis}

Results are expressed by mean \pm SEM. Significance between groups was evaluated using Student's $t$-test. For multiple comparisons, one- way analysis of variance (ANOVA) and $p<0.05$ was considered significant: $\left(^{*}\right)$ for HFD vs. SD, and $(\$)$ for HFD + GSSE vs. HFD. $\left(^{* *}\right)$ and (\$S) for $p<0.01$.

\section{Results}

\section{Grape seed and skin extract composition}

Phenolics levels found in GSSE from Carignan cultivar prepared in $\mathrm{H} 2 \mathrm{O}, 10 \%$ Ethanol and 100\% Ethanol were given in Table 1. Total phenolics, flavonoids and condensed tannins were slightly higher in the $100 \%$ ethanol extract than $10 \%$ ethanol.

Fifteen phenolic compounds were identified in $10 \%$ GSSE using GC-MS (Table 2). Among these compounds, epicatechin (35.21\%) and catechin (34.41\%) were the most abundant.

\section{Biometric parameters}

We reported in Fig. 1 the effect of HFD and GSSE on body weight evolution over time. Data showed that after 7 weeks long fat treatment, the animals become obese and that treatment with high dosage GSSE ( $4 \mathrm{~g} / \mathrm{kg})$ prevented efficiently bw gain till control SD animals. HFD resulted in a marked increase in lung weight (26\%) and lung lipid content (32\%). Treatment with GSSE counteracted all HFD-induced disturbances (Fig. 2). HFD was not diabetogenic as it did not affect insulinemia but was obesogenic as indicated by decreased adiponectinemia (Table 3).

\section{Lung oxidative stress status Protein carbonylation}

We evaluated the effect of HFD on lung protein carbonylation and NPSH content. HFD increased lung protein carbonylation (Fig. 3) by $95 \%(P=0.0045)$ and decreased NPSH content (Table 4$)$ by $32 \%(P=0.0291)$. GSSE counteracted efficiently the HFD-induced disturbances until control levels.

\section{Antioxidant enzyme GPx activity}

Furthermore, HFD decreased the antioxidant enzyme GPx activity (Fig. 3 ) by $25 \%(P=0.0074)$. GSSE backed HFD-induced drop in GPx to near control and GSSE on its own increased GPx activity by $30 \%$.

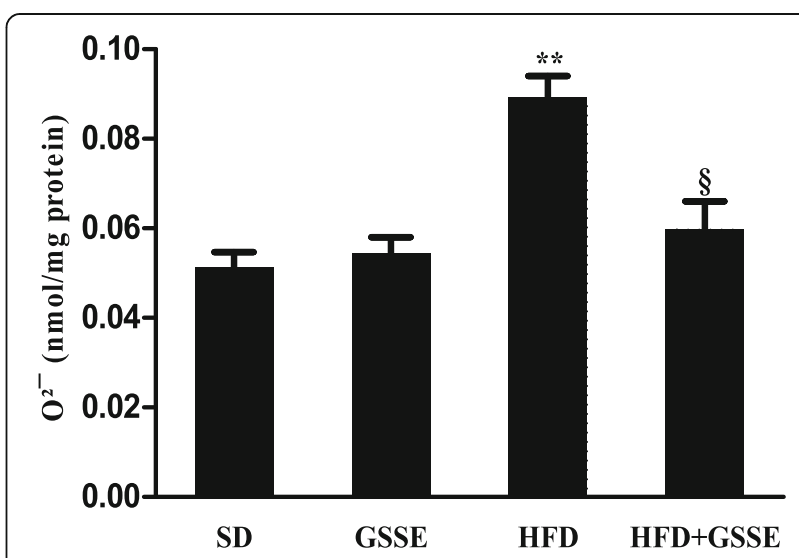

Fig. 4 Effect of HFD and GSSE on lung $\mathrm{O}^{2-}$ activity. Results are expressed as mean \pm SEM $(N=6)$. $p<0.05$ was considered significant: $\left(^{*}\right)$ for HFD vs. SD, and (§) for HFD + GSSE vs. HFD. $\left(*^{*}\right)$ and $(\S \S)$ for $p<0.01$ 


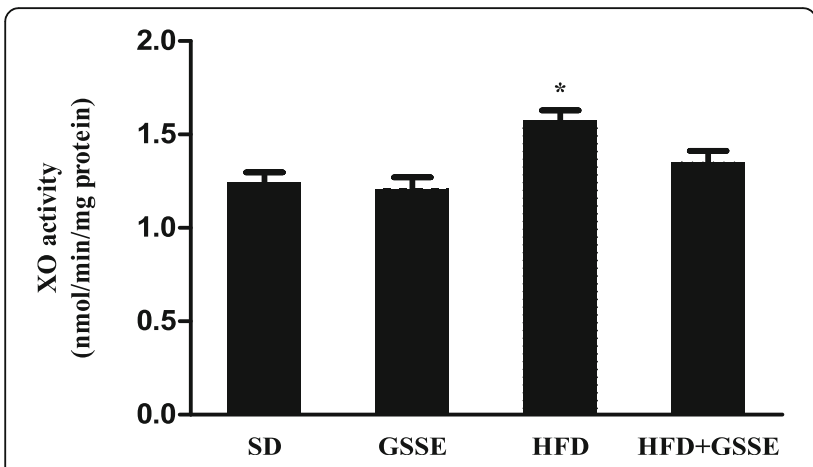

Fig. 5 Effect of HFD and GSSE on xanthine oxidase activity (XO). Results are expressed as mean $\pm \operatorname{SEM}(N=6) . p<0.05$ was considered significant: $\left(^{*}\right)$ for HFD vs. SD, and (§) for HFD + GSSE vs. HFD. $\left(^{* *}\right)$ and $(\S \S)$ for $p<0.01$

\section{ROS measurement}

We further asked whether HFD affect $\mathrm{O}^{2-}$ lung level. Data clearly showed that HFD increased $\mathrm{O}^{2-}$ (Fig. 4) by $59 \%(P=0.0027)$ and that GSSE treatment backed them to near control level.

\section{Xanthine oxidase activity}

We then sought to determine the impact of HFD on xanthine oxidase activity (XO), which is associated with the production of free radicals. HFD increased lung $\mathrm{XO}$ activity (Fig. 5$)$ by $27 \%(P=0.0122)$. GSSE counteracted the impact of HFD as it restored the enzyme activity to near control level.

\section{Metals ions measurement and some associated enzymes} HFD induced depletion of $\mathrm{Cu}^{2}+$ by $24 \%(P=0.0498)$ and decreased $\mathrm{Pb}$ by $(51 \%)(P=0.0490)$. HFD decreased the copper dependent enzyme tyrosinase activity by $29 \%$ $(P=0.0500)$ and increased the -manganese dependingglutamine synthetase activity $(\mathrm{GS})$ by $31 \%(P=0.0027)$ (Table 5). GSSE efficiently counteracted the effect of HFD on metal ions and the associated enzyme activities disturbances.

\section{Lung energy metabolism status \\ Creatine kinase activity}

HFD affected also on creatine kinase activity (CK) which plays a key role on the energetic metabolism. HFD highly increased lung CK activity (Fig. 6) by $23 \%(P=0.0108)$, while GSSE reversed these HFD induced disturbance to control level.

\section{Krebs cycle enzyme activities}

We interested next to determine the MDH activity, which is an enzyme of Krebs cycle. Data showed that HFD decreased MDH activity (Fig. 7 ) by $27 \%(P=0.0120)$. GSSE backed them to near control level.

\section{Activity of mitochondrial respiratory chain complex IV}

Finally, we assessed the effect of HFD activity on mitochondrial respiratory chain complex IV. HFD highly decreased the enzyme activity (Fig. 8$)$ by $31 \%(P=0.0086)$. GSSE corrected this activity to near control level.

\section{Discussion}

The present paper deals with the effect of HFD on rat lung as well as the putative protection offered by GSSE.

HFD induced lipotoxicity was assessed by altered body weight, lung weight and lipid content. However, HFD induced body weight gain, provoked lipotoxicity without affecting insulinemia and decreased adiponectinemia. HFD-induced lipotoxicity also generated an oxidative stress into the lungs. Thus, HFD increased lung carbonylation, decreased non protein thiols and altered antioxidant enzyme activities as GPx. Our data fully agree with several previous works in the field [16, 30-32], who showed that HFD provoked an oxidative stress in the heart, liver, brain, kidney and muscles and particularly with the recent work of Charradi et al. [32] who showed that HFD increased carbonylation and dropped NPSH in brain. Moreover, we showed that HFD depresses GPx activity. Furthermore, our results showed that HFD also elicited an increase in harmful ROS, as superoxide. The increase in superoxide likely results from the inhibition in SOD activity that occurs upon HFD- induced lipotoxicity. HFD induced lung oxidative stress was also characterized by elevated activity of xanthine oxidase, which is associated with the production of free radicals and formation of uric acid. Our data are in line with previous studies [33-35] who demonstrated that elevated $\mathrm{XO}$ activity and uric acid levels are known to correlate with obesity. Similarly, Kelley et al. [32] showed that HFD increasing lung XO activity.

Table 5 Effect of HFD and GSSE on Copper; Lead; tyrosinase activity and glutamine synthetase activity

\begin{tabular}{|c|c|c|c|c|}
\hline & SD & GSSE & HFD & HFD + GSSE \\
\hline $\mathrm{Cu} 2+(\mathrm{mg} / \mathrm{L})$ & $286 \pm 22.72$ & $359.4 \pm 33.32$ & $216.5 \pm 10.45^{*}$ & $308.2 \pm 13.6^{\S}$ \\
\hline $\mathrm{Pb}(\mu \mathrm{g} / \mathrm{L})$ & $1673 \pm 266.8$ & $1637 \pm 234.4$ & $813.7 \pm 152.2^{*}$ & $1575 \pm 173^{\S}$ \\
\hline Tyrosinase activity (U/ mg protein) & $0.1383 \pm 0.01239$ & $0.1423 \pm 0.006984$ & $0.09833 \pm 0.007356^{*}$ & $0.1393 \pm 0.005783$ \\
\hline Glutamine synthetase activity ( $\mathrm{nmol} / \mathrm{min} / \mathrm{mg}$ protein) & $1.947 \pm 0.04842$ & $1.913 \pm 0.1618$ & $1.353 \pm 0.1179^{*}$ & $1.667 \pm 0.1168^{\S}$ \\
\hline
\end{tabular}

Results are expressed as mean \pm SEM $(N=6) . p<0.05$ was considered significant: $\left(^{*}\right)$ for HFD vs. SD, and (§) for HFD + GSSE vs. HFD. $\left({ }^{* *}\right)$ and $(\S \S)$ for $p<0.01$ 


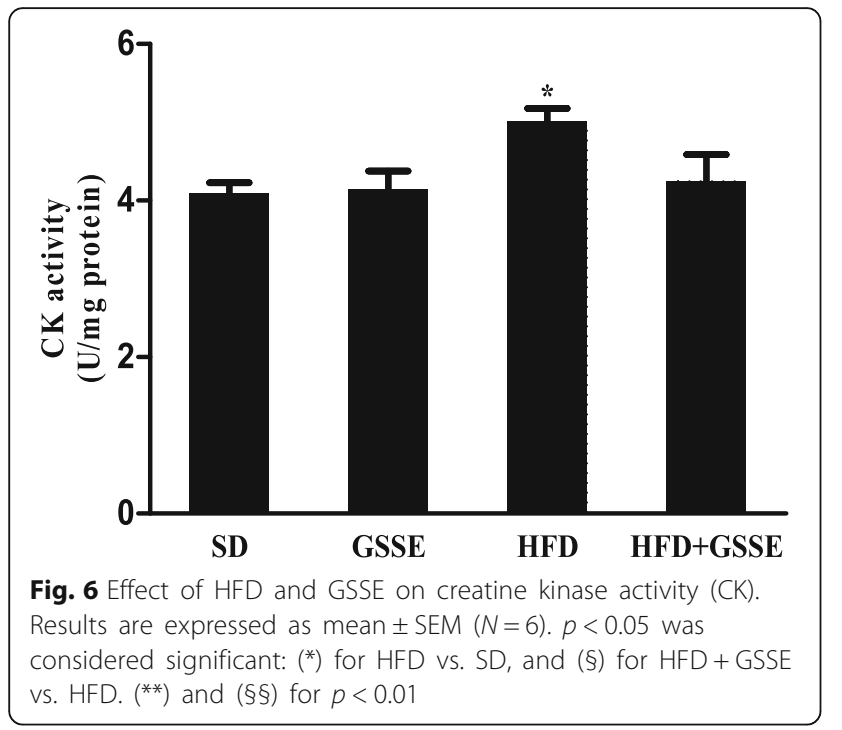

The effect of HFD on lung metals ions level showed that it induced the depletion of $\mathrm{Cu}^{2}+$ and $\mathrm{pb}^{2+}$. These data were further supported by the similar variation that occurred in copper dependent enzyme such as tyrosinase as well as on glutamine synthetase activity. Whereas we found that HFD induced a clear drop in GS activity, which play a key role in glutamine homeostasis. However and during physiological stress, the lung should increase production of the amino acid glutamine to maintain glutamine homeostasis [36]. Noteworthy that in our current study, HFD has affect copper and their associated enzyme tyrosinase. To the best of our knowledge, our data are the first to link HFD induced oxidative stress in the lung with the dyshomeostasis of copper and plumb i.e. depletion of copper and a drastic depletion of plumb.

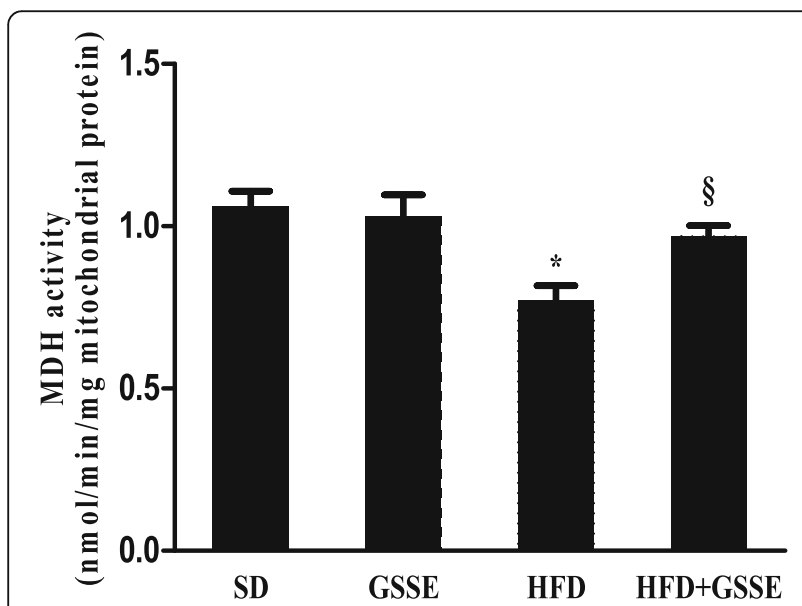

Fig. 7 Effect of HFD and GSSE on malate dehydrogenase activity $(\mathrm{MDH})$. Results are expressed as mean $\pm \mathrm{SEM}(N=6) . p<0.05$ was considered significant: (*) for HFD vs. SD, and (§) for HFD + GSSE vs. HFD. $\left(^{* *}\right)$ and $(\S \S)$ for $p<0.01$
Another relevant effect of HFD is its ability to affect energy metabolism [37-39]. The overall role of intermediary metabolism in cell homeostasis is primarily to generate the requisite energy for cellular functions and to provide the small molecular weight substrates for biosynthetic processes. In lung cells as in most tissues, a variety of substrates derived from protein, lipid and carbohydrate precursors can enter the cellular pool of intermediary metabolites. Thus, lung tissue can oxidize to different degrees glucose, fatty acids, amino acids and lactate $[39,40]$. However, the rate of glucose oxidation is greatest [41]. The adenosine triphosphate (ATP) content of the normal perfused lung is approximately 2 to 2.5 $\mu$ mole/g lung weight. This is similar to ATP values for rat brain, liver and kidney. However, our data showed that HFD increased the lung CK activity, which is the central regulatory enzyme of energy metabolism.

In addition, HFD altered the Krebs cycle enzymes activity by decreasing MDH activity.

$(-27 \%)$ which is a key enzyme and affected the electron transport chain by increasing complex IV enzyme activity $(-31 \%)$. This is can be partially explained by the increased resistance imposed by the presence of excess fatty tissue on the chest and abdomen, which causes mechanical disadvantage to these muscles and production of energy will be increased.

The current finding that GSSE can be benefic in the context of obesity induced pulmonary complication is novel. Although the mechanism underlying this effect are not completely clear. The use of nutraceutical in dyslipidemia has been studied previously [42]. Many molecules has proved beneficial effects on dyslipidemia such as resveratrol [43], water-insoluble fish proteins from Alaska Pollock [44] and curcumin [45]. However

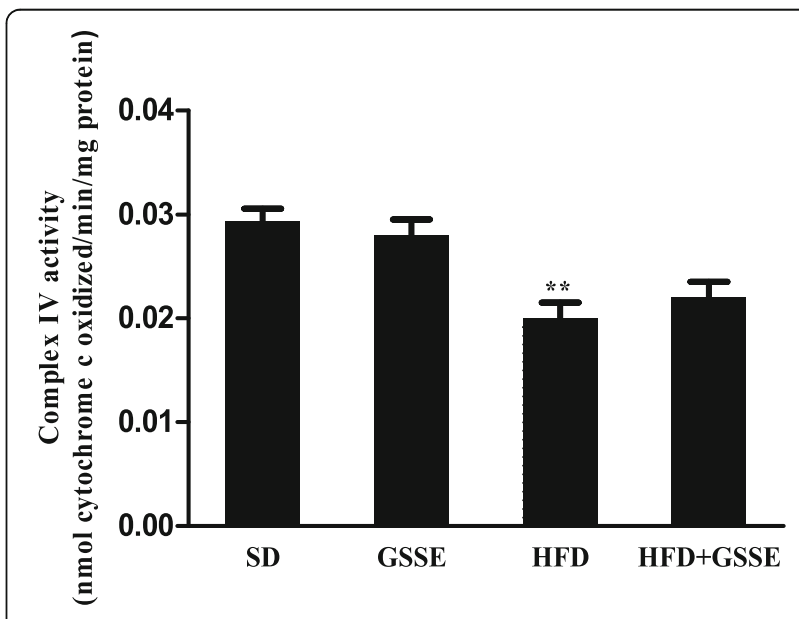

Fig. 8 Effect of HFD and GSSE on cytochrome c oxidase (complex IV). Results are expressed as mean \pm SEM $(N=6)$. $p<0.05$ was considered significant: $\left(^{*}\right)$ for HFD vs. SD, and (§) for HFD + GSSE vs. HFD. $\left(^{* *}\right)$ and $(\S \S)$ for $p<0.01$ 
mechanisms are not fully understood and might implicate several pathways. In the current study we present evidence that increased stress oxidative, energy metabolism deregulation are present in our model, and undoubtedly, the most relevant result drawn is the protection offered by GSSE against HFD-induced lung lipotoxicity, oxidative stress and dysregulation energy metabolism. We do not yet know which kind of GSSE containingpolyphenol is at the basis of such protection. Our present data are in favor of a synergism between the numerous GSSE-containing polyphenols rather than the specific effect of a single compound.

In conclusion, we have demonstrated that GSSE has beneficial effects in reversing almost all the negative effects of HFD on lung. The research work provides evidence that GSSE supplementation in rats with obesity induced by HFD protected against oxidative stress and energy metabolism dysregulation in the lung. Finally, the effects of GSSE on HFD-induced rats indicate that GSSE possesses anti-obesity effects and may curtail obesityrelated symptoms, including pulmonary complication like asthma [46] and raise the possibility of new applications. Such results should emphasizes the use of GSSE supplementation in everyday life of over-weighted persons and opens perspectives for clinical trials.

\section{Abbreviations}

ATP: Adenosine triphosphate; CK: Creatine kinase; GC-MS: Gaz chromatography-mass spectrometry; GPx: Glutathione peroxidase; GS: Glutamine synthase; GSSE: Grape seed and skin extract; HFD: High fat diet; MDH: Malate dehydrogenase; SD: Standard diet; XO: Xanthine oxidase

\section{Acknowledgements}

We would like to think Dr. Madhuvanti Kale.

\section{Availability of data and materials}

The datasets generated during and/or analysed during the current study are available from the corresponding author on reasonable request.

\section{Authors' contributions}

EM and KS performed the all the experiments of the article, MM helped in the analyze and interpretation of results. AE helped in the interpretation of the results and the manuscript redaction. ES conducted the work and wrote most of the manuscript and corrected it.

\section{Ethics approval}

The animal use was done accordingly to the $\mathrm{NIH}$ guidelines.

\section{Competing interests}

The authors declare that they have no competing interests.

\section{Publisher's Note}

Springer Nature remains neutral with regard to jurisdictional claims in published maps and institutional affiliations.

Received: 20 October 2017 Accepted: 23 April 2018

Published online: 10 May 2018

\section{References}

1. World Health Organization, WHO, Obesity: Preventing and Managing the Global Epidemic. Report of a WHO Consultation (WHO Technical Report Series 894). ISBN: 924120894 5. at http://www.who.int/nutrition/ publications/obesity/WHO_TRS_894/en/. Accessed 10 Feb 2016.
2. Marseglia L, Manti S, D'Angelo G, Nicotera A, Parisi E, Di Rosa G, et al. Oxidative stress in obesity: a critical component in human diseases. Int J Mol Sci. 2014;16:378-400.

3. Hodgson LE, Murphy PB, Hart N. Respiratory management of the obese patient undergoing surgery. J Thorac Dis. 2015;7:943-52.

4. Mafort TT, Rufino R, Costa CH, Lopes AJ. Obesity: systemic and pulmonary complications, biochemical abnormalities, and impairment of lung function. Multidiscip Respir Med. 2016;11:28.

5. Akaberi M, Hosseinzadeh H. Grapes (Vitis vinifera) as a potential candidate for the therapy of the metabolic syndrome. Phytother Res. 2016;30:540-56.

6. Nassiri-Asl M, Hosseinzadeh $\mathrm{H}$. Review of the pharmacological effects of Vitis Vinifera (Grape) and its bioactives constituents: An Update. Phytother Res. 2016;30:1392-403

7. Grases F, Prieto RM, Fernandez-Cabot RA, et al. Effect of consuming a grape seed supplement with abundant phenolic compounds on the oxidative status of healthy human volunteers. Nutr J. 2015;14:94.

8. Belviranli M, Gokbel H, Okudan N, Büyükbaş S. Oxidative stress and antioxidant status in diabetic rat liver: effect of plant polyphenols. Arch Physiol Biochem. 2012;118:237-43.

9. Quesada H, Díaz S, Pajuelo D, Fernández-Iglesias A, Garcia-Vallvé S, Pujadas $G$, et al. The lipid-lowering effect of dietary proanthocyanidins in rats involves both chylomicron-rich and VLDL-rich fractions. Br J Nutr. 2012;108:208-17.

10. Ohyama K, Furuta C, Nogusa Y, Nomura K, Miwa T, Suzuki K. Catechin-rich grape seed extract supplementation attenuates diet-induced obesity in C57BL/6J mice. Ann Nutr Metab. 2011;58:250-8.

11. Carpene C, Gomez-Zorita S, Deleruyelle S, Carpene MA. Novel strategies for preventing diabetes and obesity complications with natural polyphenols. Curr Med Chem. 2015;22:150-64.

12. Singleton VL, Rossi JA. Colorimetry of total phenolics with phosphomolybdicphosphotungstic acid reagents. Am J Enol Vitic. 1965;16:144-58.

13. Dewanto V, Wu X, Adom KK, Liu RH. Thermal processing enhance the nutritional value of tomatoes by increasing total antioxidant activity. J Agric Food Chem. 2002:50:3010-4

14. Sun B, Ricardo da Silva JM, Spranger I. Critical factors of vanillin assay for catechins and proanthocyanidins. J Agric Food Chem. 1998:46:4267-74.

15. Erbing B, Jansson P, Widmalm G, Nimmich W. Structure of the capsular polysaccharide from the Klebsiella K8 reference strain 1015. Carbohydr Res. 1995;273:197-20.

16. National Research Council. Guide for the Care and the Use of Laboratory Animals, vol. 20. Bethesda: National Institute of Heath; 1985. p. 85-123.

17. Aloui F, Charradi K, Hichami A, Subramaniam S, Khan NA, Limam F, Aouani E. Grape seed and skin extract reduces pancreas lipotoxicity, oxidative stress and inflammation in high fat diet fed rats. Biomed Pharmacother. 2016; https://doi.org/10.1016/j.biopha.2016.11.0172.6.

18. Folch J, Lees M, Sloane Stanley GH. A simple method for the isolation and purification of total lipides from animal tissues. J Biol Chem. 1957; 226:497-509.

19. Levine RL, Garland D, Oliver CN, et al. Determination of carbonyl content in oxidatively modified proteins. Methods Enzymol. 1990;186:464-78.

20. Ohnishi ST, Barr JK. A simplified method of quantitating protein using the biuret and phenol reagents. Anal Biochem. 1978;86:193-200.

21. Ellman GL. Tissue sulfhydryl groups. Arch Biochem Biophys. 1959;82:70-7.

22. Charradi K, Elkahoui S, Karkouch I, Limam F, Hassine FB, El May MV, Aouani E. Protective Effect of Grape Seed and Skin Extract Against High-Fat DietInduced Liver Steatosis and Zinc Depletion in Rat. Dig Dis Sci. 2014; https:// doi.org/10.1007/s10620-014-3128-0.

23. Marklund $\mathrm{S}$, Marklund $\mathrm{G}$. Involvement of the superoxide anion radical in the autoxidation of pyrogallol and a convenient assay for superoxide dismutase. Eur J Biochem. 1974;47:469-74.

24. Avis PG, Bergel F, Bray RC. Cellular constituents. The chemistry of xanthine oxidase. Part III : Estimations of the cofactors and the catalytic activities of enzyme fractions from cow's milk. J Chem Soc. 1956:1219-26. http://pubs. rsc.org/en/Content/ArticleLanding/1956/JR/jr9560001219\#!divAbstract.

25. Worthington Biochemical Corporation. Worthington Enzyme Manual Worthington Biochemical Corp, Freehold; 1977. p. 74-5.

26. Santoro JC, Harris G, Sitlani A. Colorimetric detection of glutamine synthetasecatalyzed transferase activity in glucocorticoid-treated skeletal muscle cells. Anal Biochem. 2001;289:18-25.

27. Liang LP, Patel M. Iron-sulfur enzyme mediated mitochondrial superoxide toxicity in experimental Parkinson's disease. J Neurochem. 2004;90:1076-84. 
28. Kitto GB. Intra and extramitochondrial malate dehydrogenases from chicken and tuna heart. Methods Enzymol. 1969;13:106-16.

29. Ragan CL, Wilson MT, Darley-Usmar M, Lowe PN. Subtractionation of mitochondria, and isolation of the protein of oxidative phosphorylation. In: Darley-Usmar VM, Rickwood D, Wilson MT, editors. Mitochondria: A Practical Approach. London: RL Press; 1987. p. 79-112.

30. Desai VG, Feuers RJ, Hart RW, Ali SF. MPP+ induced neurotoxicity in mouse is age-dependent: evidenced by the selective inhibition of complexes of electron transport. Brain Res. 1996;715:1-8.

31. Charradi K, Mahmoudi M, Elkahoui S, Limam F, Aouani E. Grape seed and skin extract mitigates heart and liver oxidative damage induced by a high-fat diet in the rat: gender dependency. Can J Physiol Pharmacol. 2013;91:1076-85.

32. Charradi K, Mahmoudi M, Bedhiafi T, Kadria S, Elkahoui S, Limam F, Aouani E. Dietary supplementation of grape seed and skin flour mitigates brain oxidative damage induced by a high-fat diet in rat: Gender dependency. Biomed Pharmacother. 2017;87:519-26.

33. Kelley EE, Baust J, Bonacci G, Golin-Bisello F, Devlin JE, St. Croix CM, et al. Fatty acid nitroalkenes ameliorate glucose intolerance and pulmonary hypertension in high-fat diet-induced obesity. Cardiovasc Res. 2014;101:352-63.

34. Tam HK, Kelly AS, Fox CK, Nathan BM, Johnson LA. Weight loss mediated reduction in xanthine oxidase activity and uric acid clearance in adolescents with severe obesity. Child Obes. 2016; https://doi.org/10.1089/chi.2015.0051.

35. Haan YC, Oudman I, Diemer FS, Karamat FA, Van Valkengoed IG, Van Montfrans GA, Brewster LM. Creatine kinase as a marker of obesity in a multi-ethnic population. Mol Cell Endocrinol. 2016; https://doi.org/10.1016/j. mce.2016.11.022

36. Brian I, Labow SF, Abcouwer SF, Lin CM, Willey WS. Glutamine synthetase expression in rat lung is regulated by protein stability. Am J Phys. 2017;275:877-86.

37. Galgani J, Ravussin E. Energy metabolism, fuel selection and body weight regulation. Int J Obes. 2008;32:109-19.

38. Eo H, Park JE, Jeon YJ, Lim Y. Ameliorative effect of Ecklonia cava polyphenol extract on renal inflammation associated with aberrant energy metabolism and oxidative stress in high fat diet-induced obese mice. J Agric Food Chem. 2017;1:2-36

39. Patel DP, Krausz KW, Xie C, Beyoğlu D, Gonzalez FJ, Idle JR. Metabolic profiling by gas chromatography-mass spectrometry of energy metabolism in high-fat diet-fed obese mice. PLoS One. 2017;12 https://doi.org/10.1371/ journal.pone.0177953.

40. Bassett DJ, Hamosh R, Hamosh M, Rabinowitz J. Pathways of palmitate metabolism in the isolated rat lung. Exp Lung Res. 1981;2:37-47.

41. Wolfe RR, Hochachka PW, Trelstad RL, Burke JF. Lactate metabolism in perfused rat lung. Am J Phys. 1979;236:276-82.

42. Scicchitano P, Cameli M, Maiello M, Modesti PA, Muiesan ML, Novo S, et al. Nutraceuticals and dyslipidaemia: Beyond the common therapeutics. J Funct Foods. 2014;6:11-32.

43. Chen $\mathrm{Q}$, Wang $E, M a L$, Zhai P. Dietary resveratrol increases the expression of hepatic 7a-hydroxylase and ameliorates hypercholesterolemia in high-fat fed C57BL/6J mice. Lipids Health Dis. 2012:11:56

44. Kato M, Ogawa H, Kishida T, Ebihara K. The mechanism of the cholesterollowering effect of water-insoluble fish protein in ovariectomised rats. $\mathrm{Br} \mathrm{J}$ Nutr. 2009;102:816-24.

45. Zhao J-F, Ching L-C, Huang Y-C, Chen C-Y, Chiang A-N, Kou YR, et al. Molecular mechanism of curcumin on the suppression of cholesterol accumulation in macrophage foam cells and atherosclerosis. Mol Nutr Food Res. 2012;56:691-701.

46. Franssen FM, O'Donnell DE, Goossens GH, Blaak EE, Schol AM. Obesity and the lung: 5. Obesity and COPD. Thorax. 2008:63:1110-7.

\section{Ready to submit your research? Choose BMC and benefit from:}

- fast, convenient online submission

- thorough peer review by experienced researchers in your field

- rapid publication on acceptance

- support for research data, including large and complex data types

- gold Open Access which fosters wider collaboration and increased citations

- maximum visibility for your research: over $100 \mathrm{M}$ website views per year

At BMC, research is always in progress.

Learn more biomedcentral.com/submissions 